\title{
AN INTRADERMAL STUDY OF THE LOCAL ANAESTHETIC AND VASCULAR EFFECTS OF THE ISOMERS OF BUPIVACAINE
}

\author{
C. APS
}

Anaesthetic Department, St Thomas' Hospital, London SE1 7EH

FELICITY REYNOLDS

Department of Pharmacology, St Thomas' Hospital Medical School, London SE1 7EH

$1 \mathrm{~L}(-)$ - and $\mathrm{D}(+)$-bupivacaine in eight different concentrations from 0.06 to $7.69 \mathrm{mmol} / \mathrm{l}$ $(0.002-0.25 \%)$ and physiological saline were given intradermally to seventeen volunteers, using a double-blind technique.

2 Local colour changes were observed as 'nil', 'pink' or 'pale' and analgesia to pinprick was assessed every $10 \mathrm{~min}$ to give an estimate of apparent in vivo potency and duration of action (50\% recovery).

3 Both isomers were vasodilator in all cases at $7.69 \mathrm{mmol} / \mathrm{l}$, but the incidence of vasodilatation waned with decreasing concentration, more rapidly with $L(-)$ - than with $D(+)$-bupivacaine.

4 Only L(-)-bupivacaine showed a vasoconstrictor effect. This was maximal at a concentration of $0.48 \mathrm{mmol} / 1$, when the incidence of pallor was $92 \%$.

5 (-)-bupivacaine had a longer duration of analgesic action than the (D+)-isomer from $0.48-3.84 \mathrm{mmol} / \mathrm{l}$; this was reflected in a higher apparent in vivo potency.

\section{Introduction}

Local anaesthetics developed since 1945 all possess an asymmetric carbon atom and exist as two optical isomers. It has been shown that $\mathrm{L}(+)$-prilocaine (Akerman, Persson \& Tegner, 1967), L(+)mepivacaine and L(-)-bupivacaine (Luduena, Bogado \& Tullar, 1972) all act for longer than their enantiomorphs, despite equal in vitro potency. In the case of mepivacaine, Ảberg \& Wahlström (1969, 1972) showed that the $\mathrm{L}(+)$-isomer had a much more marked contractile effect on rat portal vein than the $D(-)$-isomer, though for bupivacaine there was no significant difference between the isomers. Concentrations, also, affect vasoactivity in the skin (Reynolds, Bryson \& Nicholas, 1976; Aps \& Reynolds, 1976) and tension in the rat portal vein (Åberg \& Wahlström, 1972). We therefore examined the local anaesthetic and vascular activity and duration of action of $\mathrm{L}(-)$ - and $\mathrm{D}(+)$-bupivacaine given intradermally to volunteers over a range of eight concentrations.

\section{Methods}

\section{Solutions}

All solutions were isosmotic with physiological saline and were prepared in separate batches of individually and randomly coded sterile ampoules. The concentrations of $\mathrm{L}(-)$ - and $\mathrm{D}(+)$-bupivacaine ranged from 0.06 to $7.69 \mathrm{mmol} / 1(0.002-0.25 \%)$ at two-fold intervals.

\section{Subjects}

Subjects were seventeen fit adults, seven female and ten male, aged 19-40 years. Two were ourselves and the remainder informed, consenting medical students. There were three studies; in each study each subject received four concentrations of both isomers of bupivacaine and physiological saline (Table 1). One subject took part in all three studies and thirteen in two. Numbers were limited by the supply of the optical isomers.

\section{Procedure}

Subjects received a pair of intradermal injections of $0.1 \mathrm{ml}$ of each solution; eighteen injections were therefore given to each subject in each study. Injections were made $40 \mathrm{~mm}$ apart on the flexor surfaces of both forearms. Just before analgesia was tested, but after the initial blanching had waned, colour changes were assessed by both of us in every case. Every $10 \mathrm{~min}$ each bleb was tested with a lancet five times and the number of times the prick felt sharp 
was recorded until sensation had returned to normal. As an estimate of duration, $50 \%$ recovery was taken as the time at which a pair of blebs reached the combined score of five out of ten. If this score was passed during a $10 \mathrm{~min}$ period, $50 \%$ recovery was recorded at the intermediate 5 minutes.

\section{Results}

\section{Analgesic activity}

The mean pinprick scores are presented graphically as percentage recovery against time in Figure 1 . There is no difference in analgesic activity between the isomers at $7.69 \mathrm{mmol} / \mathrm{l}$. At $3.84 \mathrm{mmol} / \mathrm{l} \mathrm{L}(-)$-bupivacaine produces more analgesia than $\mathrm{D}(+)$-bupivacaine. The difference is significant, using a paired $t$-test within individuals and combining the scores for 10, 20 and $30 \mathrm{~min} \quad(P<0.01)$. At lower concentrations the difference between the mean scores is significant as shown in Figure 1. As the concentration is reduced, the difference between the isomers lasts for a decreasing length of time.

In Figure $2 \mathrm{a}$ the effect of concentration on the mean analgesia score for 10,20 and $30 \mathrm{~min}$ combined is shown for each isomer. The difference between the isomers is significant from $0.48-3.84 \mathrm{mmol} / 1$ but is not significant above or below these concentrations. The $10 \mathrm{~min}$ analgesia scores alone for the different solutions are shown in Figure $2 \mathrm{~b}$.

Table 1 Mean \pm s.e. mean duration of analgesia

\begin{tabular}{|c|c|c|c|}
\hline & \multirow[b]{2}{*}{$\begin{array}{l}\text { Concen- } \\
\text { tration } \\
\text { (mmol/l) }\end{array}$} & \multicolumn{2}{|r|}{$\begin{array}{l}\text { Duration of analgesia } \\
\text { (min) } 50 \% \text { recovery }\end{array}$} \\
\hline & & $n$ & $D(+)$ \\
\hline Study I & $\begin{array}{l}7.69 \\
3.84 \\
1.92 \\
0.96 \\
\text { Saline }\end{array}$ & $\begin{array}{l}6 \\
6 \\
6 \\
6 \\
6\end{array}$ & $\begin{array}{ll}35.8 \pm 5.2 & 35.8 \pm 6.3 \\
28.3 \pm 4.4 & 22.5 \pm 3.6 \\
29.2 \pm 5.2 & 26.7 \pm 5.3 \\
26.7 \pm 7.6 & 25.0 \pm 6.7 \\
5.83 \pm 0.83 & \end{array}$ \\
\hline Study II & $\begin{array}{l}3.84 \\
1.92 \\
0.96 \\
0.48 \\
\text { Saline }\end{array}$ & $\begin{array}{l}12 \\
12 \\
12 \\
12 \\
11\end{array}$ & $\begin{array}{c}39.6 \pm 8.821 .7 \pm 3.7 \\
38.8 \pm 10.019 .2 \pm 3.9 \\
29.6 \pm 4.517 .7 \pm 3.0 * \\
18.3 \pm 2.410 .8 \pm 2.5 \\
5.45 \pm 0.45\end{array}$ \\
\hline Study III & $\begin{array}{l}0.48 \\
0.24 \\
0.12 \\
0.06 \\
\text { Saline }\end{array}$ & $\begin{array}{l}14 \\
14 \\
14 \\
14 \\
14\end{array}$ & $\begin{array}{rr}21.4 \pm 2.3 & 16.4 \pm 2.4 \\
9.6 \pm 1.7 & 4.6 \pm 1.8 \\
5.7 \pm 1.4 & 4.3 \pm 1.3 \\
5.4 \pm 2.4 & 2.9 \pm 0.7 \\
1.79 \pm 0.66\end{array}$ \\
\hline
\end{tabular}

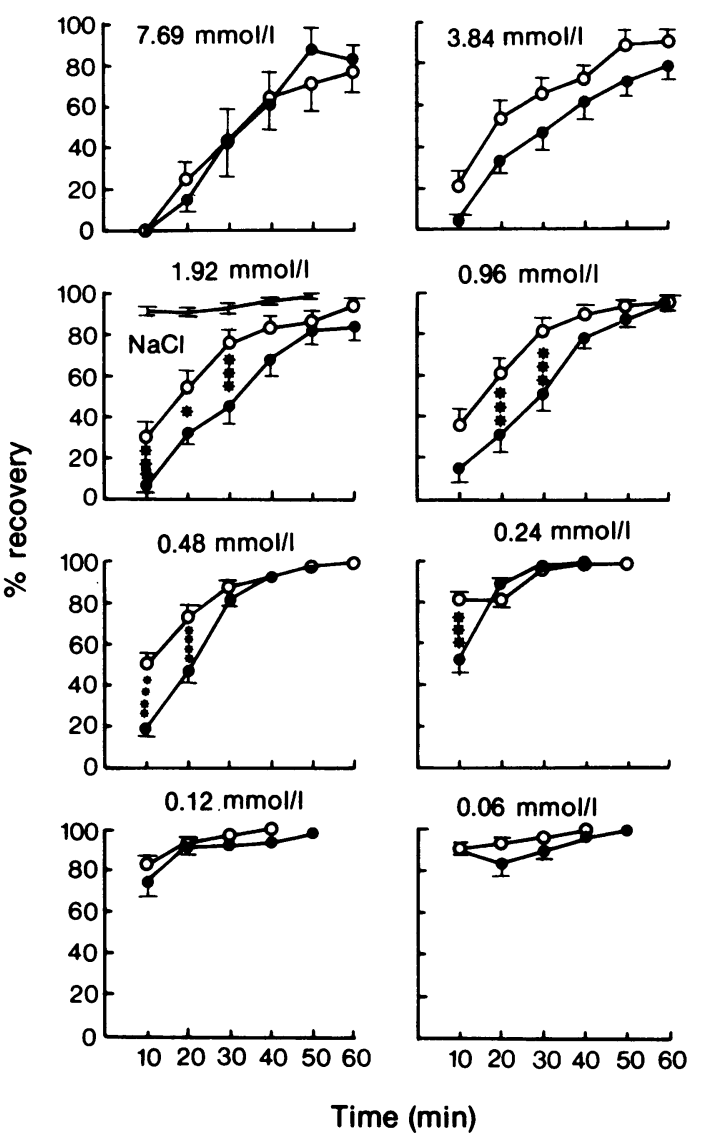

Figure 1 Mean \pm s.e. mean pinprick scores presented as \% recovery against time. Concentration (mmol/l) of $L(-)$-bupivacaine $(O)$ and $D(+)$-bupivacaine $(O)$ is shown above each graph. The score for physiological saline is shown for comparison on the graph for $1.92 \mathrm{mmol} /$. Difference between $\mathrm{L}(-)$ - and $D(+)$ - bupivacaine scores : $P<0.05, \cdots P<0.02$, $\cdots p<0.01$, $P<0.001, n$ as in Figure 2.

\section{Duration}

Table 1 shows the $50 \%$ recovery times of the different concentrations of the two isomers. $\mathrm{L}(-)$-bupivacaine is longer acting than $\mathrm{D}(+)$-bupivacaine. The difference between them, combining the results of the studies as appropriate, is significant at $0.48 \mathrm{mmol} / \mathrm{l}(P<0.02)$, at $0.96 \mathrm{mmol} / 1 \quad(P<0.01)$ and at $3.84 \mathrm{mmol} / 1$ $(P<0.001)$.

The duration of action of $\mathrm{D}(+)$-bupivacaine is longer than that seen with saline at a concentration of $0.48 \mathrm{mmol} / 1(P<0.001)$ and over, and that of the $\mathrm{L}(-)$-isomer at a quarter of this concentration $(P<0.02)$. 


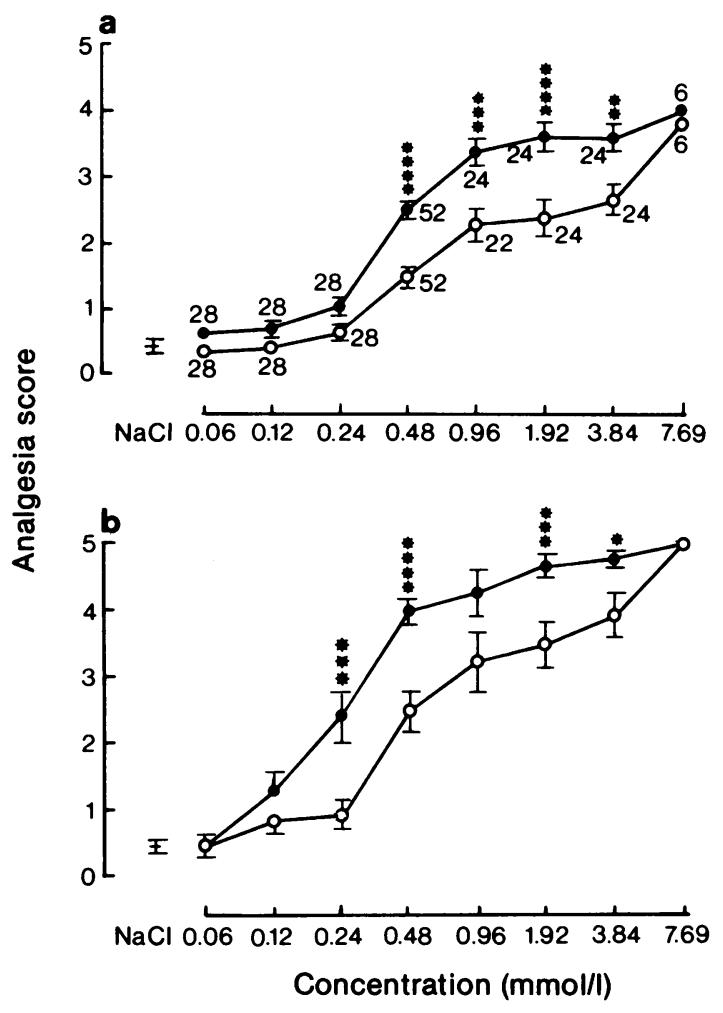

Figure 2 The effect of concentration on analgesic activity (analgesic score $=5$-pinprick score) of $L(-)$ bupivacaine $(O)$ and $D(+)$-bupivacaine (O). Vertical bars represent s.e. mean. Adjacent figures $n$.

(a) scores for 10-30 min combined. (b) scores for 10 min only, difference between $L(-)$ - and $D(+)$ bupivacaine scores: $\quad P<0.05$; $* P<0.02$; $* P<0.01 ; \cdots * P<0.001$.

\section{Local colour changes}

The colour changes in the bleb areas which were observed before stabbing, had all disappeared by the end of the experiment. In no case did bleeding or bruising occur. Colour changes were classed as pink, nil or pale and the incidence of these changes in the three studies is given in Table 2 . These results have been combined and presented graphically as percentages in Figure 3.

In Study I both $\mathrm{L}(-)$ - and $\mathrm{D}(+)$-bupivacaine produced pink blebs at $7.69 \mathrm{mmol} / 1$ in all cases. In order to establish the difference between the isomers in Study II concentrations below this level were used. Study II suggested that the incidence of pallor was increasing with lower concentrations of the $D(+)$ isomer. Study III examined a lower range still to establish the maximum incidence of pallor.

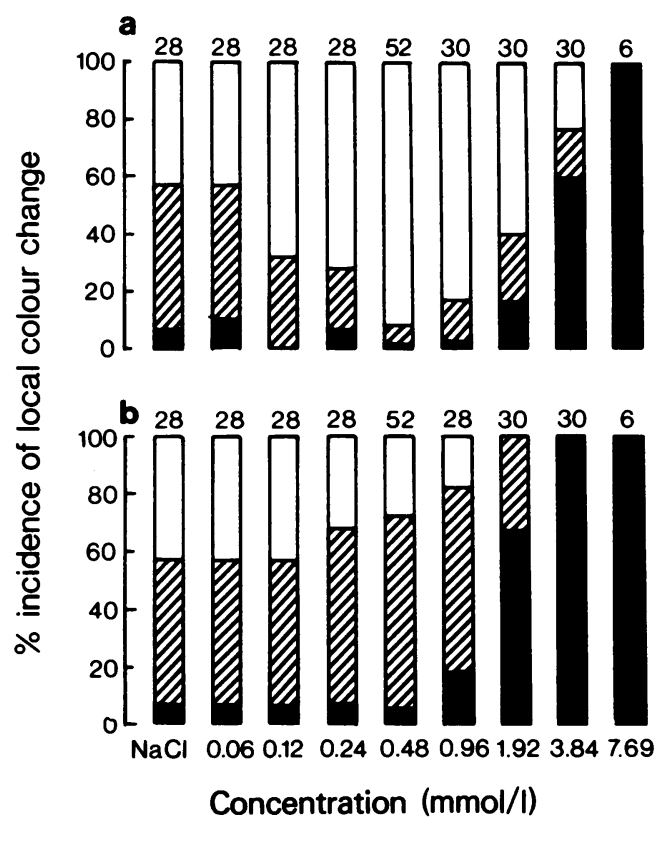

Figure $3 \%$ incidence of local colour changes for (a) $\mathrm{L}(-)$-bupivacaine and (b) $\mathrm{D}(+)$-bupivacaine ( $\mathrm{pink}$; $\mathbb{Z}$ nil and $\square$ pale). $n$ is shown at the top of each column. Changes with saline are shown on the left for comparison.

There is a significant difference between the two isomers from 0.24 to $3.84 \mathrm{mmol} / 1$ (Table 3). This difference is at a maximum at $0.48 \mathrm{mmol} / 1$ and is accounted for by the high incidence of pallor produced by the $\mathrm{L}(-)$-form at this concentration. Such a high incidence is not seen with the $D(+)$-form at any concentration.

There is no significant difference between either isomer and saline at lower concentrations (Table 3), but above $0.24 \mathrm{mmol} / 1 \mathrm{~L}(-)$-bupivacaine produces more pallor than saline; at $1.92 \mathrm{mmol} / 1$ the difference is insignificant and above this concentration it becomes more vasodilator. The $D(+)$-isomer differs from saline significantly only at and above $1.92 \mathrm{mmol} / \mathrm{l}$ when it is more vasodilator.

\section{Discussion}

The intradermal method of testing direct vasoactivity of local anaesthetics is probably the best available in man, because effects are limited to the site of injection and consequently regional, systemic and reflex effects associated with other routes of administration (Jorfeldt, Löfström, Pernow \& Wahren, 1970) are eliminated. Skin temperature changes have been 
measured thermographically (Åberg \& Adler, 1970) or by thermal conductance (de Rochemont \& Hensel, 1960). In the latter case, the results may be influenced by the pressure with which the apparatus is applied to the skin, thus the results of successive experiements may not be comparable. The method of assessment of vasoactivity we used, that is a simple 'pink', 'nil' or 'pale' decision made by mutual agreement between us, necessitates a relatively large number of subjects and a double-blind technique, but is cheap and produces consistent results.

At the highest concentration in this study both $\mathrm{D}(+)$ - and $\mathrm{L}(-)$-bupivacaine are vasodilator, while at intermediate concentrations the latter is significantly more vasocontrictor and at the lowest concentrations both isomers are indistinguishable from saline. There is a qualitative difference in vasoconstrictor activity between the isomers. While the maximum incidence of pallor with $\mathrm{L}(-)$-bipivacaine is $92 \%$ (at $0.48 \mathrm{mmol} / \mathrm{l}$ ) the incidence with $\mathrm{D}(+)$-bupivacaine never. exceeds

Table 2 Local colour changes

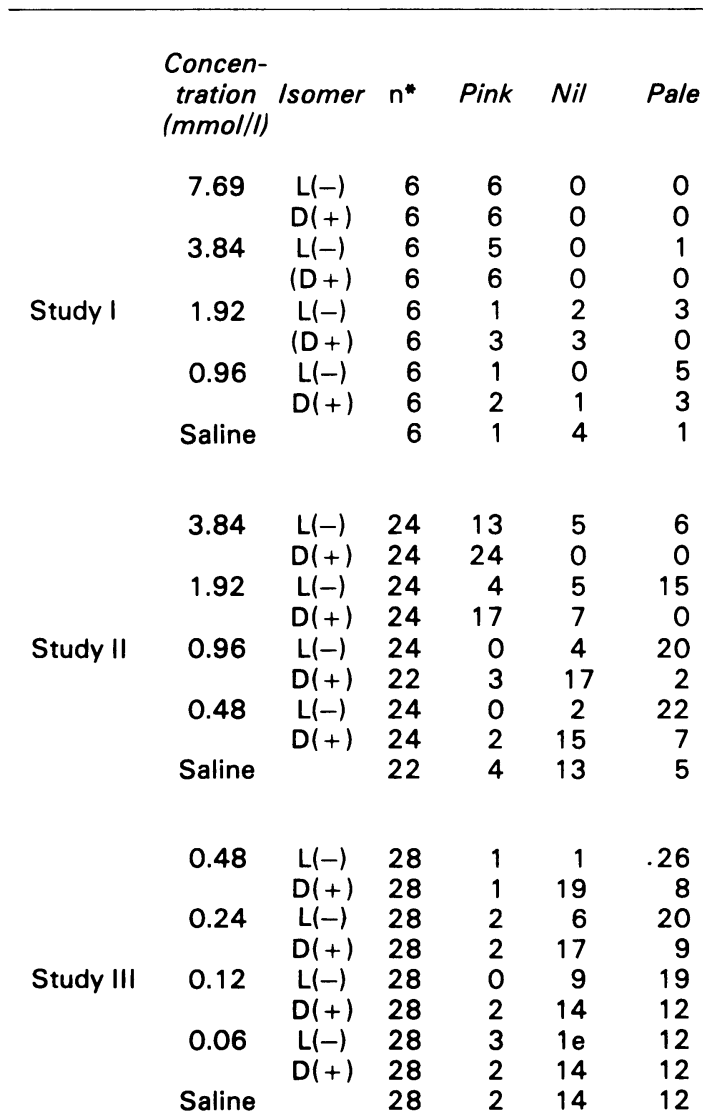

* In Study I blebs were assessed in pairs, in II \& III they were assessed individually. that with saline (43\%). Pallor associated with intradermal saline occurred with increased frequency in Study III, and more frequently than in previous investigations (Reynolds et al., 1976; Aps \& Reynolds, 1976). The present work was carried during the summer, and although the laboratory temperature was constant $\left(22^{\circ} \mathrm{C}\right)$, by the third study skin pigmentation in the fourteen subjects, all of whom had taken part in previous studies, had increased. It would appear from this work therefore that only L(-)-bupivacaine is vasoconstrictor, and pallor associated with both isomers at low concentration and with saline is purely occlusive.

A dual effect on smooth muscle has often been observed. Thus low concentrations of mepivacaine and lignocaine increase tension in the rat portal vein, while higher concentrations relax it (Åberg, 1972a). Many local anaesthetics may relax contracted but contract relaxed smooth muscle (Åberg \& Dhuner, 1972). Åberg \& Wahlström (1972) showed that while $\mathrm{L}(+)$-mepivacaine increased tension more than its enantiomorph, the $D(-)$-isomer, at low concentrations, produced more relaxation. They showed no significant difference between the isomers of bupivacaine, both of which produced relaxation at concentrations at which $\mathrm{L}(+)$-mepivacaine produced maximal contraction. It is possible that they did not explore low enough concentrations of bupivacaine since in the present study we have shown a clear difference between the isomers, and evidence of a vasocontrictor effect with L(-)-bupivacaine. Between different drugs vasoconstrictor and local anaesthetic potency are not directly related since, when given intradermally at concentrations used clinically, racemic mepivacaine may produce vasoconstriction (Reynolds et al., 1976) while racemic bupivacaine usually produces vasodilatation (Aps \& Reynolds, 1976).

Table 3 Colour changes: statistical differences

\begin{tabular}{lccc}
\hline Comparison & $\begin{array}{c}\text { Concen- } \\
\text { tration } \\
\text { (mmol/l) }\end{array}$ & $\chi^{2}$ & $\mathrm{P}$ \\
$\mathrm{L}(-)$ with $\mathrm{D}(+)$ & $\leqslant 0.12$ & 4.67 & $\mathrm{NS}$ \\
& 0.24 & 9.43 & $<0.01$ \\
& 0.48 & 45.3 & $<<0.001$ \\
& 0.96 & 15.4 & $<0.001$ \\
& 1.92 & 27.5 & $<<0.001$ \\
& 3.84 & 15.0 & $<0.001$ \\
& 7.69 & 0 & $\mathrm{NS}$ \\
Saline with $\mathrm{L}(-)$ & $\leqslant 0.24$ & 5.2 & $\mathrm{NS}$ \\
& 0.48 & 37.5 & $<<0.001$ \\
& 0.96 & 10.4 & $<0.01$ \\
& 1.92 & 4.75 & $\mathrm{NS}$ \\
& 3.84 & 18.3 & $<0.001$
\end{tabular}


The vasoconstrictor effect of low concentrations of local anaesthetics other than cocaine appears not to be due to noradrenaline uptake inhibition (Äberg, Morck \& Waldeck, 1973). Áberg \& Anderson (1972a) suggest that it is associated with mobilization of tissue bound $\mathrm{Ca}^{++}$.

It was suggested (Aps \& Reynolds, 1976; Reynolds et al., 1976) that the vasodilatation we observed previously with high local anaesthetic concentrations was due to irritation, since it was associated with an increased incidence of bleeding and bruising. Such haemorrhagic changes were not observed in the present study in which bupivacaine concentration was probably below the irritant level. Áberg (1972a) suggested that local anaesthetics at high concentrations relax smooth muscle by stabilizing the membrane surrounding $\mathrm{Ca}^{++}$stores, thereby inhibiting $\mathrm{Ca}^{++}$release.

At the low concentrations of bupivacaine that we found necessary to examine vasoactivity in this study, duration of analgesic action is very short. Washout from the site of injection rapidly reduces the concentration of local anaesthetic to below the threshold anaesthetic concentration. In other words, time affects the pinprick score in exactly the same way as does a reduction of bupivacaine concentration. This is shown by the serial graphs in Figure 1.

Bülbring \& Wajda (1945) suggested that potency of a local anaesthetic could be assessed using the guineapig intradermal wheal method by combining the scores for the first $\mathbf{3 0}$ minutes. Our results suggest that it is impossible to separate potency from duration of action by the intradermal technique, since variation in washout from the tissues cannot be eliminated. Vascular changes appear to bend the log dose-

\section{References}

ABERG, G. (1972a). Myogenic action of local anaesthetics on smooth muscle; role of $\mathrm{Ca}^{++}$and cyclic AMP. Acta Pharmac. tox., 31, Suppl. I, 46.

ABERG, G. (1972b). Toxicological and local anaesthetic effects of optically active isomers of two local anaesthetic compounds. Acta pharmac. tox., 31, 273-286.

ABERG, G. \& ADLER, R. (1970). Thermographic registrations of some vascular effects of a local anaesthetic compound. Swed. Dent. J., 63, 671-677.

ABERG, G. \& ANDERSSON,|R. (1972). Studies on mechanical actions of mepivacaine (Carbocaine $\left.{ }^{R}\right)$ and its optically active isomers on isolated smooth muscle: role of $\mathrm{Ca}^{++}$ and cyclic AMP. Acta pharmac. tox., 31, 321-336.

ABERG, G. \& DHUNER, K-G. (1972). Effects of mepivacaine (Carbocaine ${ }^{R}$ ) on femoral blood flow in the dog. Acta pharmac. tox., 30, 267-272.

ABERG, G., MORCK, E. \& WALDECK, B. (1973). Studies on the effects of some local anaesthetics on the uptake of ${ }^{3} \mathrm{H}-1$-noradrenaline into vascular and cardiac tissues in vitro. Acta pharmac. tox., 33, 476-480. response curves as depicted in Figures $2 a$ and $b$. Even at $10 \mathrm{~min}$ (Figure $2 \mathrm{~b}$ ) the vasoconstrictor $\mathrm{L}(-$ )isomer appears to have a higher in vivo potency, though there is no difference in the nerve blocking efficacy of the isomers of bupivacaine or mepivacaine in vitro (Åberg, 1972b). Similarly, Akerman et al. (1976) found the potencies of the two isomers of prilocaine equal in vitro though not in vivo.

$\mathrm{L}(-)$ bupivacaine is clearly longer acting than its enantiomorph between 0.48 and $3.84 \mathrm{mmol} / 1$, and this difference is associated with marked difference in vasoactivity over this range. At $7.69 \mathrm{mmol} / 1$ durations are identical, correlating with the vasodilator activity that both isomers exert. Within each isomer duration increases with concentration in the range $0.24-1.92 \mathrm{mmol} / \mathrm{l}$. Such a relationship has not been observed at higher concentrations of racemic bupivacaine and other local anaesthetics (Aps \& Reynolds, 1976; Reynolds et al., 1976).

Because Åberg \& Wahlström (1972) found negligible difference in vascular effects between the two isomers of bupivacaine, Aberg (1972b) suggested that the much longer duration of infiltration anaesthesia he found with $\mathrm{L}(-)$ bupivacaine might be due to a difference in tissue penetrability. However, in the present work there appears to be a good correlation between vascular and local anaesthetic effect, and the maximum disparity in both effects between the isomers occurs at the same concentration $(0.48 \mathrm{mmol} / \mathrm{l})$. The present work appears therefore to confirm the suggestion of Luduena (1969) that the difference in duration of action between the two isomers of bupivacaine is due to difference in vasoactivity.

Reprint requests should be addressed to F.R.
ÁBERG, G. \& WAHLSTROM, B. (1969). Vascular effects of mepivacaine. Acta physiol. Scand., Suppl. 330, 71.

ABERG, G. \& WAHLSTROM, B. (1972). Mechanical and electrophysiological effects of some local anaesthetic agents and their isomers on the rat portal vein. Acta pharmac. tox., 31, 255-266.

AKERMAN B., PERSSON, H. \& TEGNER, C. (1967). Local anaesthetic properties of the optically active isomers of prilocaine (Citanest). Acta pharmac. tox., 25, 233-241.

APS, C. \& REYNOLDS, F. (1976). The effect of concentration on vasoactivity of bupivacaine and lignocaine. Br. J. Anaesth., 48, 1171-1174.

BÜLBRING, E. \& WAJDA, I. (1945). Biological comparison of local anaesthetics. J. Pharmac. exp. Ther., 85, 78-84.

JORFELDT, L., LÖFSTROM, B., PERNOW, B. \& WAHREN, J. (1970). The effect of mepivacaine and lidocaine on forearm resistance and capacitance vessels in man. Acta Anaesthesiol. Scand., 14, 183-201.

LUDUENA, F.P. (1969). Duration of local anesthesia. Ann. Rev. Pharmac., 9, 503-520. 
LUDUENA, F.P., BOGADO, E.F. \& TULLAR, B.F. (1972). Optical isomers of mepivacaine and bupivacaine. Arch. int. Pharmacodyn., 200, 359-369.

REYNOLDS, F., BRYSON, T.H.L. \& NICHOLAS, A.D.G. (1976). Intradermal study of a new local anaesthetic agent: aptocaine. Br. J. Anaesth., 48, 347-354. de ROCHEMONT, W.Du.M. \& HENSEL, H. (1960). Messung der Hautdurchblutung am Meschen bei Einwirkung verschiedener Lokalanaesthetica. Arch. exp. Path. $u$. Pharmak., 239, 464-474.

(Received June 28, 1977) 